\title{
Chironomid larvae inhabiting bromeliad phytotelmata in a fragment of the Atlantic Rainforest in Rio de Janeiro State
}

\author{
Sodré, $V M .^{\mathrm{a}, \mathrm{c} *}$, Rocha, $O{ }^{\mathrm{b}}{ }^{\mathrm{b}}$ and Messias, $M C{ }^{\mathrm{c}}$ \\ aPrograma de Pós-Graduação em Ecologia e Recursos Naturais, Universidade Federal de São Carlos - UFSCar, \\ Rodovia Washington Luís, Km 235, SP-310, CEP 13565-905, São Carlos, SP, Brazil \\ bDepartamento de Ecologia e Biologia Evolutiva, Universidade Federal de São Carlos - UFSCar, \\ Rodovia Washington Luís, Km 235, SP-310, CEP 13565-905, São Carlos, SP, Brazil
}

${ }^{\mathrm{c}}$ Museu Nacional, Departamento de Entomologia, Quinta da Boa Vista, Universidade Federal do Rio de Janeiro - UFRJ, Bairro Imperial de São Cristóvão, CEP 20940-040, Rio de Janeiro, RJ, Brazil

*e-mail: viniciusmoraessodre@hotmail.com

Received November 11, 2009 - Accepted October 28, 2009 - Distributed August 31, 2010

(With 7 figures)

\begin{abstract}
A study of chironomids (Diptera, Chironomidae) occurring in phytotelmata of Bromeliaceae was carried out in a fragment of the Atlantic Rain Forest in an area of the city of Magé, Pau Grande, one of the metropolitan areas of Rio de Janeiro City, during a period of 13 months between September 2006 and September 2007. Eight samplings were performed at intervals of $1 \frac{1 / 2}{2}$ months and the content of the phytotelmata of the bromeliad species Neoregelia concentrica (Vellozo) L.B. Smith, 1934 and Aechmea nudicaulis (Linnaeus) Grisebach, 1864, were examined. A taxonomical inventory and evaluation of the numerical abundance of Chironomidae larvae were performed in 50 specimens of the bromeliads, being 13 individuals of $N$. concentrica and 37 of A. nudicaulis. Three taxa of Chironomidae belonging to three distinct subfamilies were recorded: Polypedilum sp., Orthocladiinae genus A and Monopelopia sp. A total of 293 individuals of Chironomidae, were recorded, being 9 Polypedilum sp., 233 Orthocladiinae genus A, and 51 Monopelopia sp., the latter representing the first record of Monopelopia in phytotelmata in Rio de Janeiro State. Considering all samples, a mean density of $3.32 \pm 2.62$ chironomid larvae per phytotelmata was recorded. There was a positive relationship between the chironomid abundance and both precipitation and the volume of water in the phytotelmata. Apparently there is no preference by the chironomids regarding the colonistion of the bromeliad species.
\end{abstract}

Keywords: invertebrates, bromeliad fauna, Chironomidae, Atlantic Forest.

\section{Larvas de Chironomidae (Insecta, Diptera) em fitotelmata de Bromeliaceae em um fragmento de Mata Atlântica no Estado do Rio de Janeiro}

\begin{abstract}
Resumo
Um estudo dos Chironomidae presentes em fitotelmata de duas espécies de bromélias com ocorrência em um fragmento de Mata Atlântica de uma área do município de Magé, Pau Grande, uma das áreas metropolitanas do Estado do Rio de Janeiro, por um período de 13 meses, entre setembro de 2006 e setembro de 2007. Foram realizadas 8 coletas a intervalos de aproximadamente 1 1/2 mês e analisados o conteúdo dos fitotelmata das espécies Neoregelia concentrica (Vellozo) L.B. Smith, 1934 e Aechmea nudicaulis (Linnaeus) Grisebach, 1864. Realizou-se o estudo taxonômico e a avaliação da abundância das larvas de Chironomidae em 50 exemplares de bromélias, sendo 13 exemplares de $N$. concentrica e 37 de A. nudicaulis. Três taxons de Chironomidae pertencentes a três subfamílias distintas foram registradas: Polypedilum sp., Orthocladiinae gênero A e Monopelopia sp. No total foram coletados 293 espécimes de Chironomidae, sendo nove indivíduos de Polypedilum sp., 233 de Orthocladiinae gen. A e 51 de Monopelopia sp., este último, o primeiro registro de Monopelopia em fitotelmata para o Estado do Rio de Janeiro. Considerando-se todas as amostragens realizadas, obteve-se um valor médio de 3,32 $\pm 2,62$ de larvas de Chironomidae por fitotelmata. A abundância dos Chironomidae nos fitotelmata das bromélias variou de acordo com a precipitação e volume de água encontrado nas bromélias, não havendo preferência por parte dos Chironomidae estudados quanto ao tipo de bromélia para colonização.
\end{abstract}

Palavras chave: invertebrados, fauna bromelícola, Chironomidae, Floresta Atlântica. 


\section{Introduction}

Plants of the family Bromeliaceae, known as bromeliads, are especially adapted to develop phytotelmata, small bodies of water held in central structures formed by the characteristic arrangement of overlapping leaves in hollow rosettes (Fish, 1983).

Phytotelmata can be seen as aquatic microcosms since, despite the very small volume of rainwater collected in them, micro-communities have been found there which, relative to the size of the habitat have a very diverse range of taxa, which survive and interact as small ecosystems. Records exist of organisms of the following groups, simultaneously inhabiting the phytotelmata of a single bromeliad: Protozoa, Nematoda, Oligochaeta, copepoda, Cladocera, Ostracoda, Tardigrada, Insecta, Arachnida and Amphibia (Greeney, 2001; Kitching, 2000; Laessle, 1961; Picado, 1913). Around 470 species of aquatic animals have been recorded so far in these bromeliad tanks.

Such communities have been under study in several regions of the globe and the feature that has intrigued many researchers is the simultaneous occurrence of organisms of several trophic levels, in spite of the very limited space and low flux of energy (Kitching, 2000). Another aspect, very relevant to society at large, is the fact that phytotelmata shelter immature stages of mosquitoes such as Aedes aegypti Linnaeus, 1762 (Forattini et al., 1998; Cunha et al., 2002; Derraik, 2005), vector of dengue. On the other hand, phytotelmata communities are important as small repositories or refuges of biodiversity, particularly in habitats undergoing great changes (Armbruster et al., 2002; Noss, 1990), and also take part in forest maintenance by redistributing nutrients to the soil, as epiphytic bromeliads and their communities process nutrients before falling to the ground from the canopy.

Frank et al. (2004) warns the investigators that wish to work in the Neotropical region that they will encounter severe taxonomic problems. The effort to collect the specimens is small compared with the effort required to identify the specimens reliably to the species level. Four approaches have been suggested in attempts to unravel the mysteries of bromeliad fauna: brief reports of new discoveries, in-depth studies (behavioural or ecological or taxonomic) of a selected taxa, whole fauna inventories, and broad-scale hypothesis tests.

The immature stages of the non-biting midges (Diptera, Chironomidae) are commonly found in bromeliad water. Records of 12 species have been published: Antillocladius antecalvus Saether, 1981, Mesosmittia patrihortae Saether, 1985, Metriocnemus abdominoflavatus Picado, 1913, Ablabesmyia costaricensis Picado, 1913, Ablabesmyia ignobilis (Johannsen) Johannsen, 1932, Monopelopia caragata Mendes, Marcondes and Pinho, 2003, Monopelopia mikeschwartzi Epler, 1998, Monopelopia tillandsia Beck and Beck, 1966, Chirocladius pedipalpus, Picado 1913, Stenochironomus atlanticus Pinho and Mendes, 2005, Tanytarsus bromelicola Cranston, 2007, Tanytarsus confusa (Malloch), Miller, 1971 (Marcondes and Pinho,
2005; Cranston and Judd, 1987; Epler and Janetzky, 1998; Cranston, 2007; Pinho et al., 2005; Mendes et al. 2003).

In this study, phytotelmata, in a fragment of the Atlantic Rainforest in the until now unstudied Pau grande area of Magé district, were screened for the presence of Chironomidae larvae. The aim was to create an inventory of these dipterans in bromeliad water, as a contribution to the existing taxonomic information on the phytotelmata biota in the Neotropical region, with a view to preserving such communities.

\section{Material and Methods}

\subsection{Study area}

The town of Magé belongs to the metropolitan region of the State of Rio de Janeiro and is about $55 \mathrm{~km}$ from its capital city. The study area was a fragment of forest in the district of Pau Grande (22 34' 48' S and 43 09' 94” W), located at the edge of the conurbation of Greater Rio de Janeiro. This fragment is directly connected with some environmentally protected sites in the region, as well as with the Serra dos Órgãos National Park. Such remaining fragments of the Atlantic Rainforest form an ecological corridor that extends across almost the entire length of the state (Figure 1). The collection site is easily reached, but protected by an agreement between the local government and a drinks factory that uses the clean water from a reservoir nearby, formed by damming the River Piabetá. The study area is around $5000 \mathrm{~m}^{2}$ of forest centred on this reservoir.

\subsection{Sampling}

Eight collections were carried out in the period form September 2006 to September 2007 at intervals of 1.5 months on average: September, October, December, February, April, June, July and September. Climatological data (temperature and rainfall) for this period were obtained from the Instituto Nacional de Meteorologia (INMET) automatic weather station in Xerém, RJ, Brazil.

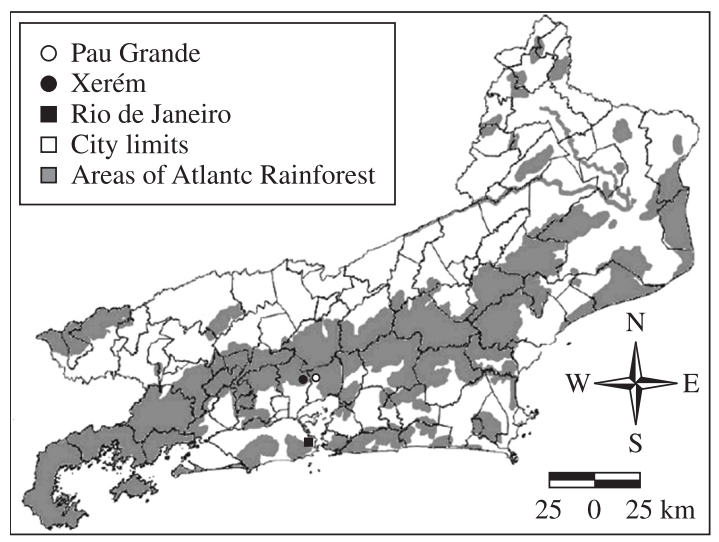

Figure 1. Location of the field site. Shaded areas represent current extent of Atlantic Rainforest in the State of Rio de Janeiro. 
An inventory was made of the phytotelmata found in 50 bromeliad specimens belonging to two species: 13 specimens of Neoregelia concentrica (Veloso) Smith and 37 of Aechmea nudicaulis (Linnaeus) Grisebach.

The Chironomidae samples were taken, on site, by aspiration of the water and organisms from the central tank of the bromeliad into a $60 \mathrm{~mL}$ syringe, through an attached silicone tube of $5.0 \mathrm{~mm}$ bore. The volume and $\mathrm{pH}$ of the water in the phytotelmata were measured. The collected fauna was fixed on site in $70 \%$ ethanol, labelled and taken to the laboratory for subsequent analysis.

Analysis of variance (ANOVA) was used to determine whether there were significant differences in water volume or $\mathrm{pH}$ between the phytotelmata of the two plant species.

In the laboratory, the material was sorted under a stereomicroscope and specimens of Chironomidae separated. These larvae were mounted in slides, as described by Schlee (1966), for later taxonomic identification with an optical microscope, with the aid of specialist keys such as those of Trivinho-Strixino (1995) and Epler (2001). The morphological terms adopted were those proposed by Saether (1980).

Selected examples of all Chironomidae material have been deposited in the Entomological Collection of the National Museum at the Federal University of Rio de Janeiro (UFRJ) in Rio, Brazil.

\section{Results}

Data on the mean air temperature and monthly rainfall in the period from September 2006 to September 2007 are shown in Figure 2. The lowest rainfall was recorded in October $2006(0.2 \mathrm{~mm})$ and the highest in June 2007 $(283 \mathrm{~mm})$. The mean temperature of the air varied from $20.6{ }^{\circ} \mathrm{C}$ in July 2007 to $27.4^{\circ} \mathrm{C}$ in March 2007.

The data on the phytotelmata, sampled in the wet and dry periods (number of samples, volume, $\mathrm{pH}$, numbers of larvae) in the bromeliads $A$. nudicaulis and $N$. concentrica, between September 2006 and September 2007, are displayed in Table 1 . In the dry period, no significant difference was observed between the mean volumes of the sampled phytotelmata in the two species, while in the wet period there was a significant difference between these volumes ( $\mathrm{p}=0.001$ ). On average, $N$. concentrica held $23.14 \mathrm{~mL}$ of water per phytotelmata and A. nudicaulis $15.03 \mathrm{~mL}$.

The $\mathrm{pH}$ of the water in the phytotelmata varied between 5.0 and 7.5 among samples, with an average of $6.18 \pm 0.61$, but there was no difference between the samples from the two plants. The $\mathrm{pH}$ rose a little in the dry period, becoming slightly more neutral, but the difference between the two periods was not significant.

The Chironomidae data were assessed jointly for all the bromeliads sampled, irrespective of the plant species. Both the total number of Chironomidae larvae and the number of samples containing them were higher in the rainy period, in both of the bromeliads.

In all the phytotelmata sampled, three morphotypes of Chironomidae, belonging to three different subfamilies, were recorded: Polypedilum sp. with 9 specimens (Chironominae), Orthocladiinae gen. A, with 233 specimens (Orthocladiinae) and Monopelopia sp. with 51 specimens (Tanypodinae). Overall, the average number of Chironomidae per phytotelmata was $3.32 \pm 2.62$.

The variation in time of the number of Chironomidae larvae and the volume of water in the phytotelmata are displayed in Figure 3, together, and a clear correlation exists between the two sets of data, except for one collection, in April (fifth collection).

The relative abundance of the three Chironomidae taxa, calculated from their respective frequency in the phytotelmata samples taken at each collection, is shown in Figure 4. The organisms belonging to Orthocladiinae gen. A clearly dominated every collection, except the fourth. Hence, Orthocladiinae genus A can be considered a constant taxon (80\%) in this habitat, while Monopelopia sp. (17\%)

Table 1. Water volumes, $\mathrm{pH}$ and number of chironomid larvae found in samples of phytotelmata in two species of bromeliad, Aechmea nudicaulis and Neoregelia concentrica, in dry and rainy periods.

\begin{tabular}{|c|c|c|c|c|c|c|c|c|}
\hline Bromeliad & Period & $\begin{array}{c}\text { Number } \\
\text { of } \\
\text { samples }\end{array}$ & $\begin{array}{l}\text { Mean } \\
\text { volume } \\
\pm \text { SD }\end{array}$ & $\begin{array}{l}\text { Total volume } \\
\text { collected } \\
(\mathbf{m L})\end{array}$ & $\begin{array}{c}\mathrm{pH} \\
\text { mean } \\
\pm \mathrm{SD}\end{array}$ & $\begin{array}{c}\text { Number of } \\
\text { chironomid } \\
\text { larvae }\end{array}$ & $\begin{array}{c}\text { Number } \\
\text { of samples } \\
\text { with } \\
\text { larvae } \\
\end{array}$ & $\begin{array}{c}\text { Number } \\
\text { of chironomids } \\
\text { per } \\
\text { sample } \pm \text { SD }\end{array}$ \\
\hline \multirow[t]{2}{*}{$\begin{array}{l}\text { Aechmea } \\
\text { nudicaulis }\end{array}$} & Rainy & 113 & $\begin{array}{c}15.04 \\
( \pm 11.47)\end{array}$ & 1699 & $\begin{array}{c}6.04 \\
( \pm 0.61)\end{array}$ & 165 & 49 & $\begin{array}{c}3.36 \\
( \pm 2.86)\end{array}$ \\
\hline & Dry & 29 & $\begin{array}{c}17.96 \\
( \pm 11.12)\end{array}$ & 521 & $\begin{array}{c}6.56 \\
( \pm 0.52)\end{array}$ & 55 & 13 & $\begin{array}{c}4.23 \\
( \pm 2.91)\end{array}$ \\
\hline \multirow[t]{2}{*}{$\begin{array}{l}\text { Neoregelia } \\
\text { concentrica }\end{array}$} & Rainy & 34 & $\begin{array}{c}23.14 \\
( \pm 14.9)\end{array}$ & 787 & $\begin{array}{c}6.16 \\
( \pm 0.62)\end{array}$ & 60 & 20 & $\begin{array}{c}3.0 \\
( \pm 2.07)\end{array}$ \\
\hline & Dry & 10 & $\begin{array}{c}17.4 \\
( \pm 8.19)\end{array}$ & 174 & $\begin{array}{c}6.4 \\
( \pm 0.21)\end{array}$ & 64 & 7 & $\begin{array}{c}2.0 \\
( \pm 0.81)\end{array}$ \\
\hline \multirow[t]{2}{*}{ Total } & Rainy & 147 & $\begin{array}{c}16.91 \\
( \pm 12.78)\end{array}$ & 2486 & $\begin{array}{c}6.07 \\
( \pm 0.61)\end{array}$ & 225 & 69 & $\begin{array}{c}3.26 \\
( \pm 2.64)\end{array}$ \\
\hline & Dry & 39 & $\begin{array}{c}17.82 \\
( \pm 10.35)\end{array}$ & 695 & $\begin{array}{c}6.52 \\
( \pm 0.47)\end{array}$ & 69 & 20 & $\begin{array}{c}3.45 \\
( \pm 2.6)\end{array}$ \\
\hline
\end{tabular}




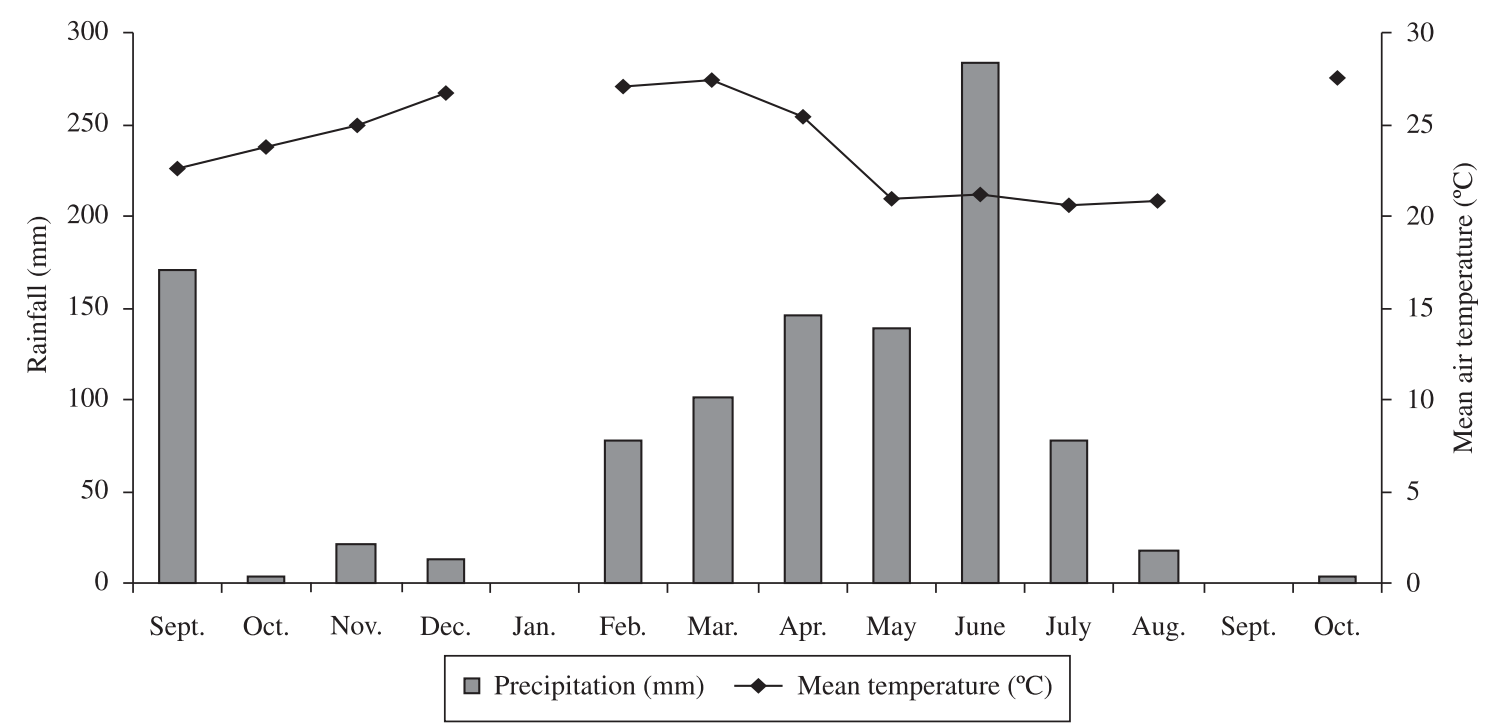

Figure 2. Variation of monthly rainfall and mean air temperature in the period from September 2006 to September 2007. The data on the months of January/2007 and September/2007 could not be computed by the automatic weather station for an unknown reason.

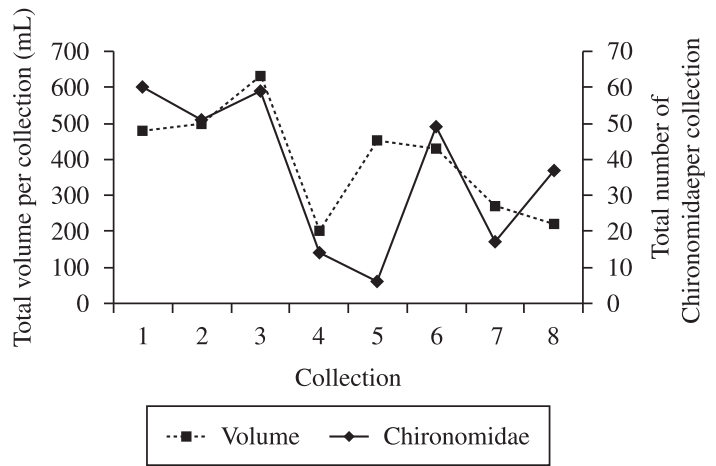

Figure 3. Variation of total volume of phytotelmata and total number of chironomid specimens found in a fragment of Atlantic Rainforest (Magé, RJ, Brazil) in the collection carried out from September 2006 to September 2007.

and Polypedilum sp. (3\%) are accidental taxa (Dajoz, 1973) (Figure 5).

The time profile of the absolute abundance of each taxon in phytotelmata of $N$. concentrica is shown in Figure 6, while the numbers in A. nudicaulis are presented in Figure 7. The variations in abundance of all taxa are quite similar in each bromeliad.

\section{Discussion}

The Atlantic Rainforest constitutes one of the richest sets of ecosystems on the planet as far as biological diversity is concerned. Most of the ecological studies on the invertebrates found in phytotelmata in this forest focus on the presence of the Culicidae, given the great importance to human health of some culicid species. The autoecology of Chironomidae in phytotelmata has rarely been studied and, in general, larvae of this family have

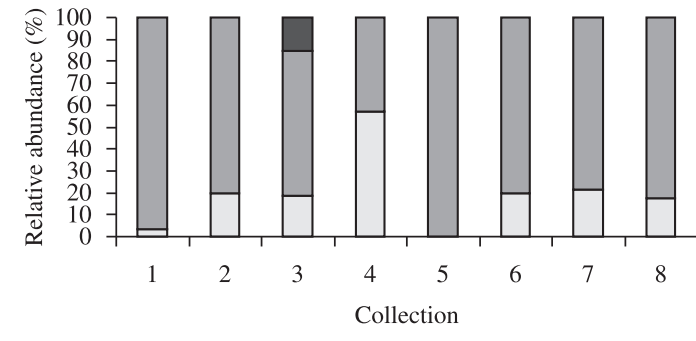

$\square$ Monopelopia sp. $\square$ Orthocladiinae gen. A $\square$ Polypedilum sp.

Figure 4. Relative abundances of 3 taxa of Chironomidae in phytotelmata of bromeliads in a fragment of Atlantic Rainforest (Magé, RJ, Brazil) in the collection carried out from September 2006 to September 2007.

been identified just at family level or recorded as belonging wide-range genera, such as Pentaneura (Cranston, 2007). Nevertheless, phytotelmata represent an important habitat for the survival of certain chironomid species, some of which may be as yet unrecorded.

This study reinforces the considerations of Frank et al., (2004) about the severe taxonomic problems in the Neotropical region and contributes with some of the approaches suggested.

The accurate taxonomic identification of the immature Chironomidae is only possible when the other stages are involved. However, although it was not possible to make such associations (attempts to rear the Chironomidae in the laboratory did not obtain the expected results), extensive literature searches in a library specialised in this group and conversations with other researchers, enabled us to classify the genera cited in this paper with taxonomic reliability. 


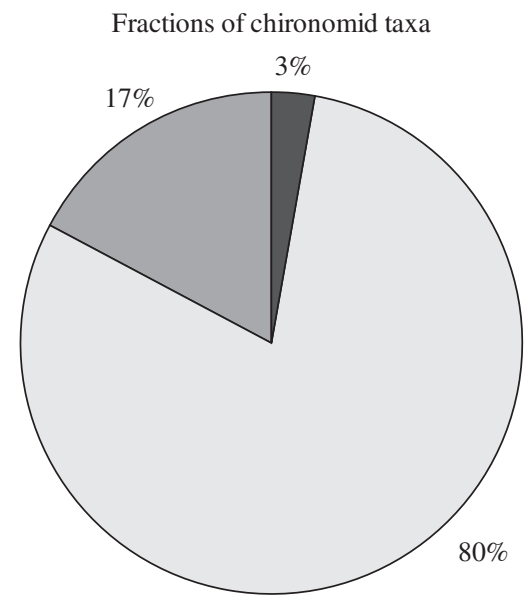

$\square$ Monopelopia sp. $\square$ Orthocladiinae gen. A $\square$ Polypedilum sp.

Figure 5. Proportions of 3 taxa of Chironomidae among specimens collected from phytotelmata of Bromeliaceae in a fragment of Atlantic Rainforest (Magé, RJ, Brazil) in the collection carried out from September 2006 to September 2007.

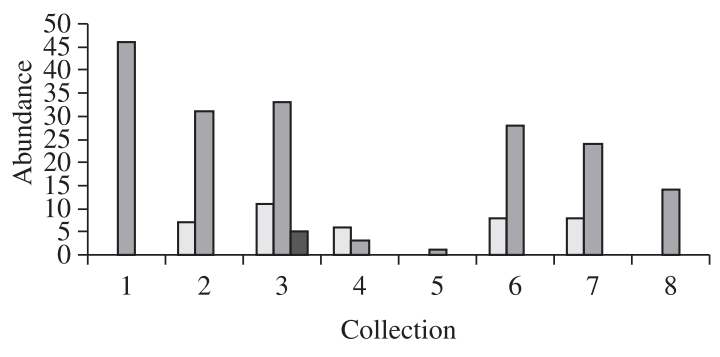

$\square$ Monopelopia sp. $\square$ Orthocladiinae gen. A $\square$ Polypedilum sp.

Figure 6. Variation in the occurrence of 3 taxa of Chironomidae in phytotelmata of Aechmea nudicaulis in a fragment of Atlantic Rainforest (Magé, RJ, Brazil) in the collection carried out from September 2006 to September 2007.

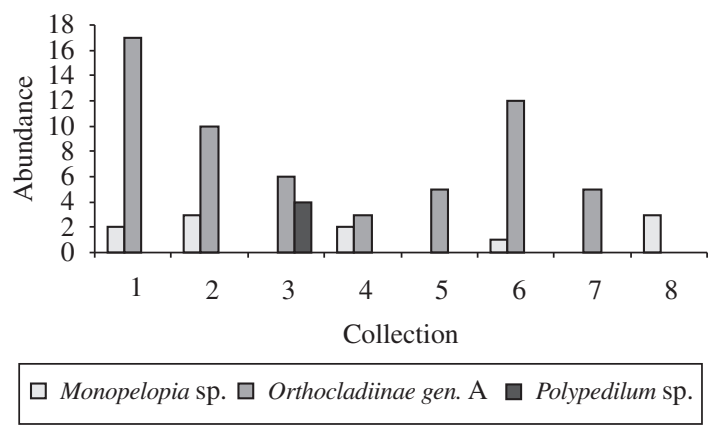

Figure 7. Variation in the occurrence of 3 taxa of Chironomidae in phytotelmata of Neoregelia concentrica in a fragment of Atlantic Rainforest (Magé, RJ, Brazil) in the collection carried out from September 2006 to September 2007.
Regarding the taxa recorded in this study, Monopelopia sp. and Polypedilum sp. have previously been recorded in phytotelmata. Thus, M. mikeschwartzi Epler,1998; M. tillandsia Beck and Beck, 1966 and M. caraguata Mendes et al., 2003 were recorded in Jamaica, US (Florida) and Brazil (Santa Catarina), respectively (Mendes et al., 2003), while Polypedilum cf.tritum was found by Epler and Janetzky (1998) in bromeliads in Jamaica and P. parthenogeneticum Donato and Paggi, 2008 was described recently in Argentina (Donato and Paggi, 2008).

The richness of the fauna in phytotelmata may be controlled by factors associated with the microhabitat in which the bromeliad grows (Araújo et.al., 2007). The plants examined in this study were well shaded, being situated beneath leafy trees. According to Lopez et al. (1998), in phytotelmata of bromeliads in restinga, the degree of exposure to the sun and not the amount of flooding of the substrate is the factor determining the taxonomic richness of the fauna. Those authors report that the species regularly inhabiting phytotelmata can successfully locate and colonise bromeliads, even in places with water bodies that hold much greater volumes of water than the plant tanks.

Accidental colonisation of the sampled phytotelmata with Polypedilum sp., recorded here, might have been due to the proximity of the nearby reservoir in which specimens of this genus have been collected (Sodré and Rocha, 2007).

This paper tried to study as deep as possible the ecological and taxonomical patterns of the chironomid's phytotelmata community inhabiting a fragment of Atlantic Rainforest in Rio de Janeiro state.

\section{Conclusions}

The abundance of Chironomidae in the phytotelmata of these bromeliads varies with monthly rainfall and the volume of water trapped in the plant. The chironomid larvae under study showed no preference for colonising either type of bromeliad.

Organisms belonging to the genus Monopelopia are apparently adapted to the phytotelmata habitat, corroborating previous accounts in the literature. This paper reports the first record of the genus Monopelopia in phytotelmata in the state of Rio de Janeiro.

The bromeliad phytotelmata found in the fragment of the Atlantic Rainforest studied represent an important habitat for conservation of the chironomid species recorded and make a contribution to the conservation of the biodiversity.

Acknowledgement - Thanks to $\mathrm{Dr}^{\mathrm{a}}$ Sonia Lopes Fraga for her kindness and support throughout the development of this study. We also thank CAPES for the financial support through the provided scholarship.

\section{References}

ARAÚJO, VA., MELO, SK., ARAÚJO, APA., GOMES, MLM. and CARNEIRO, MAA., 2007. Relationship between invertebrate fauna and bromeliad size. Brazilian Journal of Biology, vol. 67, no. 4, p. 611-617. 
ARMBRUSTER, P., HUTCHINSON, RA. and COTGREAVE, P., 2002. Factors influencing community structure in a South American tank bromeliad fauna. Oikos, vol. 96, no. 2, p. 225-234.

CRANSTON, PS. and JUDD, DD., 1987. Metriocnemus (Diptera: Chironomidae): an ecological survey and description of a new species. Journal of the New York Entomological Society, vol. 95, no. 4 , p. $534-546$

CRANSTON, PS., 2007. A new species for a Bromeliad PhytotelmDwelling Tanytarsus_(Diptera: Chironomidae). Annals of The Entomological Society of America, vol. 100, no. 5, p. 617- 622.

CUNHA, SP., ALVES, JRC., LIMA, MM., DUARTE, JR., BARROS, LCV., SILVA, JL., GAMMARO, AT., FILHO, OSM. and WANZELER, AR., 2002. Presença de Aedes aegypti em Bromeliaceae e depósitos com plantas no município do Rio de Janeiro, RJ. Revista de Saúde Pública, vol. 36, no. 2, p. 244-245.

DAJOZ, R., 1973. Ecologia geral. Petrópolis: Ed. Vozes. 472 p.

DERRAIK, JGB., 2005. Mosquitoes breeding in phytotelmata in native forests in the Wellington Region, New Zealand. New Zealand Journal of Ecology, vol. 29, no. 2, p. 185-191.

DONATO, M. and PAGGI, AC., 2008. Polypedilum parthenogeneticum (Diptera: Chironomidae): a new parthenogenetic species from Eryngium L. (Apiaceae) phytotelmata. Aquatic Insects, vol. 30, no. 1, p. 51-60.

EPLER, JH. and JANETZKY, WJ., 1998. A new species of Monopelopia (Diptera: Chironomidae) from phytotelmata in Jamaica, with preliminary ecological notes. Journal of the Kansas Entomological Society, vol. 71, no. 3, p. 216-225.

EPLER, JH., 2001. Identification manual for the Larval Chironomidae (Diptera) of Florida. Tallahassee: Florida Dept. Environmental Protection. 317 p.

FISH, D., 1983. Phytotelmata: flora and fauna. In FRANK, JH. and LOUNIBOS, LP. (Eds.). Phytotelmata: terrestrial plants as host for aquatic insect communities. New Jersey: Plexus. 293 p.

FORATTINI, OP., ALVARENGA, GR., MARQUES, M., KAKITANI, I., BRITO, M. and SALLUM, MAM., 1998. Significado epidemiológico dos criadouros de Aedes albopictus em bromélias. Revista de Saúde Pública, vol. 32, no. 2, p. 523-530.

FRANK, JH., SREENIVASAN, S., BENSHOFF, PJ., DEYRUP, MA., EDWARDS, GB., HALBERT, SE., HAMON, AB., LOWMAN, MD., MOCKFORD, EL., SCHEFFRAHN, RH., STECK, GJ., THOMAS, MC., WALKER, TJ. and WELBOURN, WC., 2004. Invertebrate animals extracted from native Tillandsia bromeliads in Sarasota County, Florida. Florida Entomologist, vol. 87, no. 2, p. $176-185$.

GREENEY, HF., 2001. The insects of plant-held waters: a review and bibliography. Journal of Tropical Ecology, vol. 17, p. 241-260.

KITCHING, RL., 2000. Food webs and container habitats: the natural history and ecology of phytotelmata. Cambridge: Cambridge University Press. 431 p.

LAESSLE, AM., 1961. A micro-limnological study of Jamaican bromeliads. Ecology, vol. 42, no. 3, p. 499-517.

LOPEZ, LCS., D'ELIAS, AMA. and IGLESIAS, R., 1998. Fatores que controlam a riqueza e a composição da fauna aquática em tanques da bromélia Aechmea bromeliifolia (Rudge) Baker, na restinga de Jacarepiá - Saquarema/RJ. Oecologia Brasiliensis, vol. 5 , no. 1, p. 91-100.

MARCONDES, CB. and PINHO, LC., 2005. First description of an emergence trap for bromeliads and preliminary results of collections from southern Brazil (Insecta: Diptera and others). Studia Dipterologica, vol. 12, no. 1, p. 3-7.

MENDES, HF., MARCONDES, CB. and PINHO, LC., 2003. A new phytotelmata species of Monopelopia Fittkau, 1962 (Insecta: Diptera: Chironomidae: Tanypodinae) from South Brazil. Zootaxa, vol. 262, p. 1-10.

NOSS, RF., 1990. Indicators for monitoring biodiversity: a hierarchical approach. Conservation Biology, vol. 4, no. 4, p. 355-365.

PICADO, C., 1913. Les broméliacées épiphytes considérées comme milieu biologique. Bulletin Scientifique France et Belgique, vol. 5, p. 215-360.

SAETHER, OA., 1980. Glossary of Chironomid morphology terminology (Diptera:Chironomidae). Entomologica Scandinavica Supplement, vol. 14, p. 1-51.

SCHLEE, D., 1966. Präparation und Ermittlung von Meßverten an Chironomidae (Diptera). Gewässer und Abwässer, vol. 41-42, p. $163-168$

SODRÉ, VM. and ROCHA, O., 2007. Sobre alguns quironomídeos (Diptera, Chironomidae) em um açude da região metropolitana do Rio de Janeiro. In Resumos do I Simpósio de Ecologia do Programa de Pós Graduação em Ecologia e Recursos Naturais. São Carlos: UFSCar. p. 298-302. (Caderno de resumos expandidos)

TRIVINHO-STRIXINO, S. and STRIXINO, G., 1995. Larvas de Chironomidae (Diptera) do Estado de São Paulo: guia de identificação e diagnose dos gêneros. São Carlos: UFSCar. 229 p. 